\title{
Endoscopic ultrasound-guided biliary drainage
} versus percutaneous transhepatic biliary drainage after failed endoscopic retrograde cholangiopancreatography: a meta-analysis

\author{
This article was published in the following Dove Press journal: \\ Clinical and Experimental Gastroenterology \\ 3 April 2017 \\ Number of times this article has been viewed
}

\section{Ramkaji Baniya \\ Sunil Upadhaya \\ Seetharamprasad Madala \\ Subash Chandra Subedi \\ Tabrez Shaik Mohammed \\ Ghassan Bachuwa}

Hurley Medical Center, Michigan State University, Flint, MI, USA
Correspondence: Ramkaji Baniya Department of Internal Medicine, Hurley Medical Center, Michigan State University, One Hurley Plaza, Suite 212, Flint, MI 48503, USA

$\mathrm{Tel}+\mathrm{I} 8102626887$

Email mail2ramkazi@gmail.com

\begin{abstract}
The failure rate of endoscopic retrograde cholangiopancreatography for biliary cannulation is approximately $6 \%-7 \%$ in cases of obstructive jaundice. Percutaneous transhepatic biliary drainage (PTBD) is the procedure of choice in such cases. Endoscopic ultrasound-guided biliary drainage (EGBD) is a novel technique that allows biliary drainage by echoendoscopy and fluoroscopy using a stent from the biliary tree to the gastrointestinal tract. Information in PubMed, Scopus, clinicaltrials.gov and Cochrane review were analyzed to obtain studies comparing EGBD and PTBD. Six studies fulfilled the inclusion criteria. Technical (odds ratio (OR): 0.34; confidence interval (CI) $0.10-1.14 ; p=0.05$ ) and clinical (OR: 1.48 ; CI $0.46-4.79 ; p=0.51$ ) success rates were not statistically significant between the EGBD and PTBD groups. Mild adverse events were nonsignificantly different (OR: 0.36 ; CI $0.10-1.24 ; p=0.11$ ) but not the moderate-to-severe adverse events (OR: 0.16; CI 0.08-0.32; $p \leq 0.00001$ ) and total adverse events (OR: 0.34; CI $0.20-0.59 ; p \leq 0.0001$ ). EGBD is equally effective but safer than PTBD.
\end{abstract}

Keywords: failed endoscopic retrograde cholangiopancreatography, percutaneous transhepatic biliary drainage, endoscopic ultrasound-guided biliary drainage, technical success, clinical success

\section{Introduction}

An estimated 500,000 endoscopic retrograde cholangiopancreatographies (ERCPs) are performed in the United States for diagnostic and therapeutic reasons. ${ }^{1,2}$ The failure rate of ERCP is approximately $6 \%-7 \%$ in cases of obstructive jaundice due to obstruction or altered anatomy. ${ }^{3,4}$ Surgical biliary decompression had been the mainstay of treatment for biliary decompression in such patients. However, it had significantly high morbidity and mortality in the postoperative period. ${ }^{5-7}$ Percutaneous transhepatic biliary drainage (PTBD) has a more favorable adverse events profile than surgical decompression but is associated with complications like fistula formation, repeat intervention, recurrent infection, and needs a long-term external catheter drainage, thereby leading to poor quality of life. ${ }^{8-10}$ Endoscopic ultrasound-guided biliary drainage (EGBD) is a novel technique that allows visualization and access of biliary tree by echoendoscopy and fluoroscopy, which was first described by Giovannini et al. ${ }^{11}$ It has the perceived benefits of being physiologic with anatomic internal drainage, improved comfort and recovery with less adverse events, and low cost. ${ }^{12}$ However, there are few studies published, to date, comparing the EGBD with PTBD 
in terms of success rate and adverse events profile in cases of failed ERCP. ${ }^{4,12-16}$ Therefore, we conducted a meta-analysis to determine the aggregated efficacy and adverse events of EGBD and PTBD in such cases of failed ERCP.

\section{Methodology}

The Preferred Reporting Items for Systematic Reviews and Meta-Analysis (PRISMA) statement for reporting metaanalysis and systematic reviews as recommended by the Cochrane Collaborative was used for this meta-analysis (Figure 1). ${ }^{17} \mathrm{~A}$ comprehensive electronic literature search was conducted for all the clinical trials on treatment of failed ERCP-guided biliary decompression between the years 2000 and 2016 on PubMed, Scopus, Cochrane library and clinicaltrials.gov using all field "failed ERCP," all field "Percutaneous biliary drainage" and all field "EUS-guided biliary drainage"; all three search headings were connected with Boolean operator "AND." Studies published in English comparing EGBD with
PTBD in cases of failed ERCP were included. Two hundred and ninety-two articles were found in the database. We included randomized controlled trials (RCTs), retrospective comparative studies and published abstracts reporting at least some adverse events. We excluded prospective non-RCTs, case reports, letters and comments. Studies were also excluded if the sample size was $<20$. Only human studies were included. A total of six studies met the above-mentioned criteria. ${ }^{4,12-16}$ Two studies were excluded as they included primary EGBD cases where ERCP was not tried as the primary procedure. ${ }^{18,19} \mathrm{~A}$ third study was excluded as they did not include the adverse event profile. ${ }^{20}$

From the selected studies, we extracted the following baseline study details (Table 1): total number of patients enrolled, number of patients in each arm, mean age, gender ratio, comorbidity index, mean pre-procedural bilirubin, mean diameter of bile duct, etiology of biliary obstruction and reasons for ERCP failure. Technical and clinical success rates (Table 2) and adverse event profile (Table 3) were also
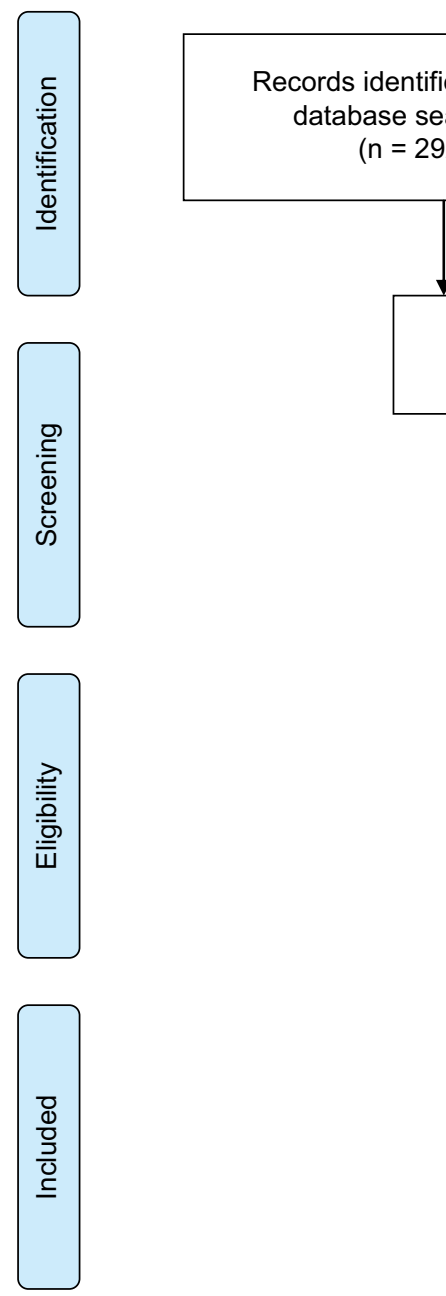 through other sources $(n=6)$

Additional records identified

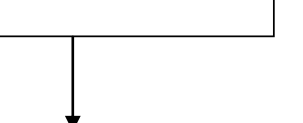

Records after duplicates removed $(n=251)$

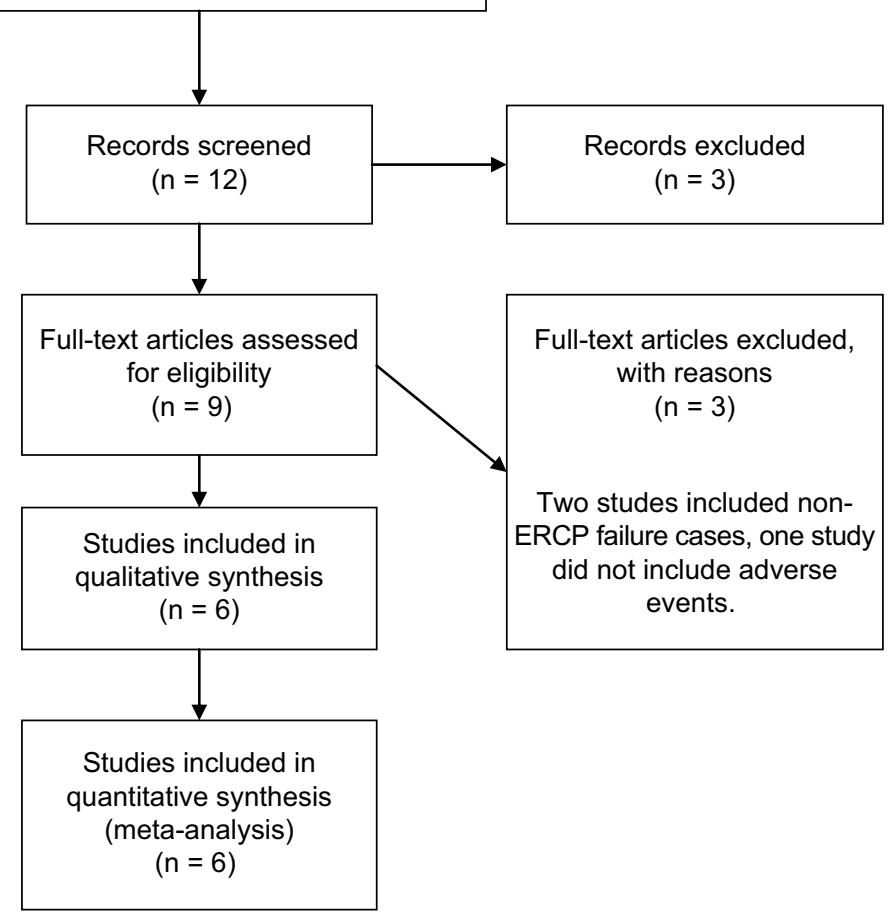

Figure I PRISMA statement of the study.

Abbreviations: PRISMA, Preferred Reporting Items for Systematic Reviews and Meta-Analysis; ERCP, endoscopic retrograde cholangiopancreatographic. 
Table I Baseline characteristics, etiology of obstruction and reason for ERCP failure

\begin{tabular}{|c|c|c|c|c|c|c|}
\hline Studies & $\begin{array}{l}\text { Artifon } \\
\text { et } \mathrm{al}^{13}\end{array}$ & Bapaye et $\mathrm{al}^{14}$ & Khashab et $a^{15}$ & $\begin{array}{l}\text { Giovannini } \\
\text { et } \mathrm{al}^{4}\end{array}$ & Lee et $\mathbf{a l}^{16}$ & Sharaiha et al ${ }^{12}$ \\
\hline Type of study & $\begin{array}{l}\text { Single-center } \\
\text { prospective } \\
\text { randomized } \\
\text { controlled trial } \\
\text { (Brazil) }\end{array}$ & $\begin{array}{l}\text { Single-center } \\
\text { retrospective } \\
\text { comparative } \\
\text { study } \\
\text { (India) }\end{array}$ & $\begin{array}{l}\text { Single-center } \\
\text { retrospective } \\
\text { comparative } \\
\text { cohort study } \\
\text { (USA) }\end{array}$ & $\begin{array}{l}\text { Multicenter } \\
\text { randomized } \\
\text { phase II trail } \\
\text { (France) }\end{array}$ & $\begin{array}{l}\text { Multicenter } \\
\text { prospective } \\
\text { randomized } \\
\text { controlled trial } \\
\text { (South Korea) }\end{array}$ & $\begin{array}{l}\text { Single-center } \\
\text { retrospective } \\
\text { cohort review } \\
\text { (USA) }\end{array}$ \\
\hline $\begin{array}{l}\text { Age (mean }[S D] / \text { median } \pm \\
\text { SD), years }\end{array}$ & $\begin{array}{l}63.4(11.1) \text { vs } \\
71.0(11.9)\end{array}$ & $\begin{array}{l}59.9 \pm 13.3 \text { vs } \\
62.4 \pm 10.2\end{array}$ & $\begin{array}{l}64.9 \pm 12.5 \text { vs } \\
66.9 \pm 12.5\end{array}$ & NA & 66.5 vs 68.4 & $\begin{array}{l}68.7 \pm 13.9 \text { vs } 58.8 \\
\pm 13.6\end{array}$ \\
\hline Male:female ratio & 2.25 vs 2.0 & 1.08 vs 1.6 & 1.2 vs I.3I & 0.91 vs 9 & 3.25 vs 3 & 12 vs 1.47 \\
\hline $\begin{array}{l}\text { Comorbidity/quality index } \\
\text { (mean) }\end{array}$ & $\begin{array}{l}58.3 \text { vs } 57.8 \\
\text { (QoL SF 36) }\end{array}$ & NA & NA & NA & $\begin{array}{l}40.7 \text { vs } 40.5 \\
\text { (Global health } \\
\text { status/QoL) }\end{array}$ & $\begin{array}{l}5.9 \text { vs } 6.4 \text { (Charlson } \\
\text { comorbidity index) }\end{array}$ \\
\hline Total bilirubin (mean), mg/dL & 16.4 vs 17.2 & $\begin{array}{l}7.11 \pm 7.6 \text { vs } \\
9.41 \pm 12.4\end{array}$ & $\begin{array}{l}15.8 \pm 11.3 \text { vs } \\
14.5 \pm 8.8\end{array}$ & NA & 10.4 vs 11.8 & NA \\
\hline $\begin{array}{l}\text { Mean diameter of bile duct } \\
\text { Etiology of obstruction }\end{array}$ & 13.7 vs 11.9 & NA & NA & NA & II. 22 vs 12.6 & NA \\
\hline Pancreatic adenocarcinoma & 10 vs 6 & 15 vs 18 & 43 & NA & 12 vs 12 & 22 \\
\hline Ampullary adenocarcinoma & I vs 0 & 5 vs 3 & 3 & NA & I vs 0 & 3 \\
\hline $\begin{array}{l}\text { Advanced lymphoma/ } \\
\text { liposarcoma }\end{array}$ & 0 vs I & 0 & 1 & NA & 0 & 0 \\
\hline Plasmacytoma & I vs 0 & 0 & 0 & NA & 0 & 0 \\
\hline Cholangiocarcinoma & I vs I & 2 vs 2 & 12 & NA & 7 vs 14 & 9 \\
\hline Gall bladder cancer & 0 & 0 & 0 & NA & 5 vs 5 & 0 \\
\hline Gastric carcinoma & 0 vs I & 0 & I & NA & 3 vs 2 & 4 \\
\hline Duodenal carcinoma & & 0 & I & NA & 3 vs 0 & 5 \\
\hline Metastasis & 0 vs 3 & 0 & 12 & NA & 3 vs I & 7 \\
\hline Total malignancy & & 0 & 37 & NA & & \\
\hline Reason for ERCP failure & & & & & & \\
\hline Inability of cannulation & 16 & 42 & 0 & NA & 0 & NA \\
\hline Duodenal/stomach invasion & 8 & 32 & 0 & NA & 22 vs 22 & NA \\
\hline Altered anatomy & 1 & 9 & 0 & NA & 12 vs 10 & NA \\
\hline Indwelling duodenal stent & 0 & 16 & 0 & NA & 0 & NA \\
\hline
\end{tabular}

Abbreviations: ERCP, endoscopic retrograde cholangiopancreatography; NA, not available; QoL, quality of life; SD, standard deviation; SF 36, the 36-Item Short Form Health Survey.

Table 2 Technical and clinical success rates of the included studies

\begin{tabular}{|c|c|c|c|c|}
\hline \multirow{2}{*}{$\begin{array}{l}\text { Study } \\
\text { (event/total cases) }\end{array}$} & \multicolumn{2}{|l|}{ Technical success } & \multicolumn{2}{|l|}{ Clinical success } \\
\hline & $\begin{array}{l}\text { EUS-guided } \\
\text { choledochoduodenostomy } \\
\text { (EGBD) }\end{array}$ & $\begin{array}{l}\text { Percutaneous } \\
\text { transhepatic biliary } \\
\text { drainage (PTBD) }\end{array}$ & $\begin{array}{l}\text { EUS-guided } \\
\text { choledochoduodenostomy } \\
\text { (EGBD) }\end{array}$ & $\begin{array}{l}\text { Percutaneous } \\
\text { transhepatic biliary } \\
\text { drainage (PTBD) }\end{array}$ \\
\hline$\overline{\text { Artifon et } \text { al }^{13}}$ & $13 / 13$ & $12 / 12$ & $13 / 13$ & $12 / 12$ \\
\hline Bapaye et al ${ }^{14}$ & $23 / 25$ & $26 / 26$ & $23 / 25$ & $26 / 26$ \\
\hline Khashab et al ${ }^{15}$ & $19 / 22$ & $51 / 51$ & $19 / 19$ & $47 / 51$ \\
\hline Giovannini et $\mathrm{al}^{4}$ & $19 / 20$ & $17 / 17$ & $18 / 19$ & $17 / 17$ \\
\hline Lee et $\mathrm{al}^{16}$ & $32 / 34$ & $31 / 32$ & $28 / 32$ & $27 / 31$ \\
\hline Sharaiha et al ${ }^{12}$ & $43 / 47$ & $12 / 13$ & $27 / 43$ & $3 / 12$ \\
\hline
\end{tabular}

Abbreviations: EUS, endoscopic ultrasound; EGBD, endoscopic ultrasound-guided biliary drainage; PTBD, percutaneous transhepatic biliary drainage.

extracted from each study. The outcomes were calculated with RevMan, version 5.2 Windows (Cochrane Collaboration, Oxford, UK). Analysis was performed by Mantel-Haenszel test. Odds ratio (OR) was calculated using $95 \%$ confidence interval (CI). A randomized model was used because of the low heterogeneity from the low number of studies. A $p$-value of $<0.05$ was considered to be significant. Technical success rate was defined as successful catheter or stent placement. Clinical success was defined as resolution of biliary obstruction without the need for repeat intervention. Biloma and perihepatic bile collection, recurrent abdominal pain, subcapsular hematoma, pancreatitis, pneumoperitoneum, hemobilia and infection of drain site or sepsis were considered mild adverse events in all the studies. Similarly, sheared guide wire, bleeding, hepatic abscess, bile leak and peritonitis, cholangitis, cutaneous leak, tube malposition or 
Table 3 Adverse events of EGBD vs PTBD

\begin{tabular}{|c|c|c|c|c|c|c|}
\hline & Artifon et $\mathrm{al}^{13}$ & Bapaye et al ${ }^{14}$ & Khashab et al $^{15}$ & Giovannini et $\mathrm{al}^{4}$ & Lee et $a^{16}$ & Sharaiha et $\mathrm{al}^{12}$ \\
\hline \multicolumn{7}{|l|}{ Mild } \\
\hline Perihepatic bile collection/biloma & I vs 0 & - & 0 vs 7 & - & - & 0 vs 1 \\
\hline Recurrent abdominal pain & - & - & - & - & - & 0 vs 3 \\
\hline Subcapsular hematoma & - & - & 0 vs 2 & - & - & - \\
\hline Pancreatitis & - & - & I vs 0 & - & I vs 0 & - \\
\hline Pneumoperitoneum & - & - & I vs 0 & - & I vs 0 & I vs I \\
\hline Hemobilia & - & - & 0 vs 5 & - & 0 vs I & - \\
\hline Infection of drain site/sepsis & - & I vs 2 & 0 vs 1 & 5 vs 7 & - & 0 vs I \\
\hline Perihepatic abscess & - & - & 0 vs I & - & - & 0 vs 1 \\
\hline \multicolumn{7}{|l|}{ Moderate } \\
\hline Sheared guide wire & - & - & I vs 0 & - & - & - \\
\hline Bleeding & I vs 0 & 0 vs I & 0 vs I & I vs 4 & - & 2 vs 1 \\
\hline Hepatic abscess & 0 vs 2 & - & 0 vs 3 & - & - & - \\
\hline Bile leak/peritonitis & 0 vs I & 4 vs 0 & 0 vs 10 & I vs 3 & I vs 4 & I vs 0 \\
\hline Cholangitis & - & 0 vs 2 & 0 vs 3 & I vs 3 & 0 vs 5 & - \\
\hline Cutaneous leak & - & 0 vs 7 & - & - & - & - \\
\hline Tube malposition/dysfunction & - & - & 0 vs 2 & - & - & 0 vs 4 \\
\hline Venous fistula & - & - & 0 vs I & - & - & - \\
\hline \multicolumn{7}{|l|}{ Severe } \\
\hline Cholecystitis & - & - & I vs 0 & - & - & - \\
\hline Re-intervention & - & - & I5.7\% vs $80.4 \%$ & - & I I vs 29 & I. 3 vs 4.9 \\
\hline Death & - & I vs 2 & & 3 vs 3 & - & - \\
\hline Total adverse events & 2 vs 3 & 6 vs 14 & 4 vs 36 & II vs 20 & 3 vs 10 & \\
\hline Cost of total procedure & USD5673 vs & NA & USD92 I $8 \pm 3772$ vs & NA & NA & NA \\
\hline (median $\pm \mathrm{SD})$ & USD7570 & & USDI8,26I $\pm 16,021$ & & & \\
\hline
\end{tabular}

Note: '-' indicates not reported.

Abbreviations: EGBD, endoscopic ultrasound-guided biliary drainage; PTBD, percutaneous transhepatic biliary drainage; SD, standard deviation; NA, not available.

dysfunction and venous fistula were considered moderate adverse events, while cholecystitis and death were considered severe adverse events (Table 3).

\section{Result}

A total of 312 and 300 patients were analyzed for the technical and clinical success rates. Technical (odds ratio (OR): 0.34; CI 0.10-1.14; $p=0.05$; Figure 2A) and clinical (OR: 1.48; CI 0.46-4.79; $p=0.51$; Table $2 \mathrm{~B}$ ) success rates were not statistically significant between the EGBD and PTBD groups (Figure 2). Similarly, there was no significant difference in the mild adverse events profile between the two groups (OR: 0.36; CI 0.10-1.24; $p=0.11$; Figure 3A). On the contrary, the moderate and severe, and total adverse events were significantly less in the EGBD group (OR: 0.16; CI $0.08-0.32 ; p \leq 0.00001$ and OR: 0.34 ; CI $0.20-0.59 ; p \leq 0.0001$, respectively; Figure 3B). Cost analysis of the procedure was done in two studies. ${ }^{13,15}$ From both the studies, it was found that EGBD was less costly compared to PTBD (Table 3 ). The re-intervention rate was also less in the EGBD group for all the three studies reporting it (Table 3C). ${ }^{12,15,16}$

\section{Discussion}

The standard technique to access the biliary tree is ERCP. The success rate of bile duct cannulation by ERCP is over
$90 \%$ in cases of unaltered upper gastrointestinal anatomy. ${ }^{15}$ The common reasons for the failed cannulation are altered or variant anatomy, ampullary pathology (stones, stenosis and tumor infiltration), periampullary diverticulum, gastric outlet obstruction, indwelling duodenal stent or previous gastric bypass surgery. ${ }^{9,21,22}$ Traditionally, such cases were managed with PTBD or surgery. ${ }^{23-27}$ The adverse events profile of these procedures is significantly high. Data show that drain occlusion, dislocation and cholangitis are the common complications with long-term PTBD therapy that lead to frequent interventions and long-term hospital stay. ${ }^{28}$ Also, patients are left with a long-term external drain which remains with the patients till the end of life, thereby, leading to poor quality of life. ${ }^{19}$ EGBD has emerged as a noble option that is feasible, extremely safe, efficacious and minimally invasive. ${ }^{29-34}$ This procedure involves accessing the biliary tree from within the lumen of the gastrointestinal system using echoendoscopy and fluoroscopy, creating a fistulous tract and deploying a stent in a single-step procedure, thus, obviating the need for external drain..$^{22,35}$ However, the success rate and adverse events rate of this procedure were unknown. Our study shows that this procedure is safe and effective with the same technical and clinical success rate at skilled centers with better adverse events profile. 
A

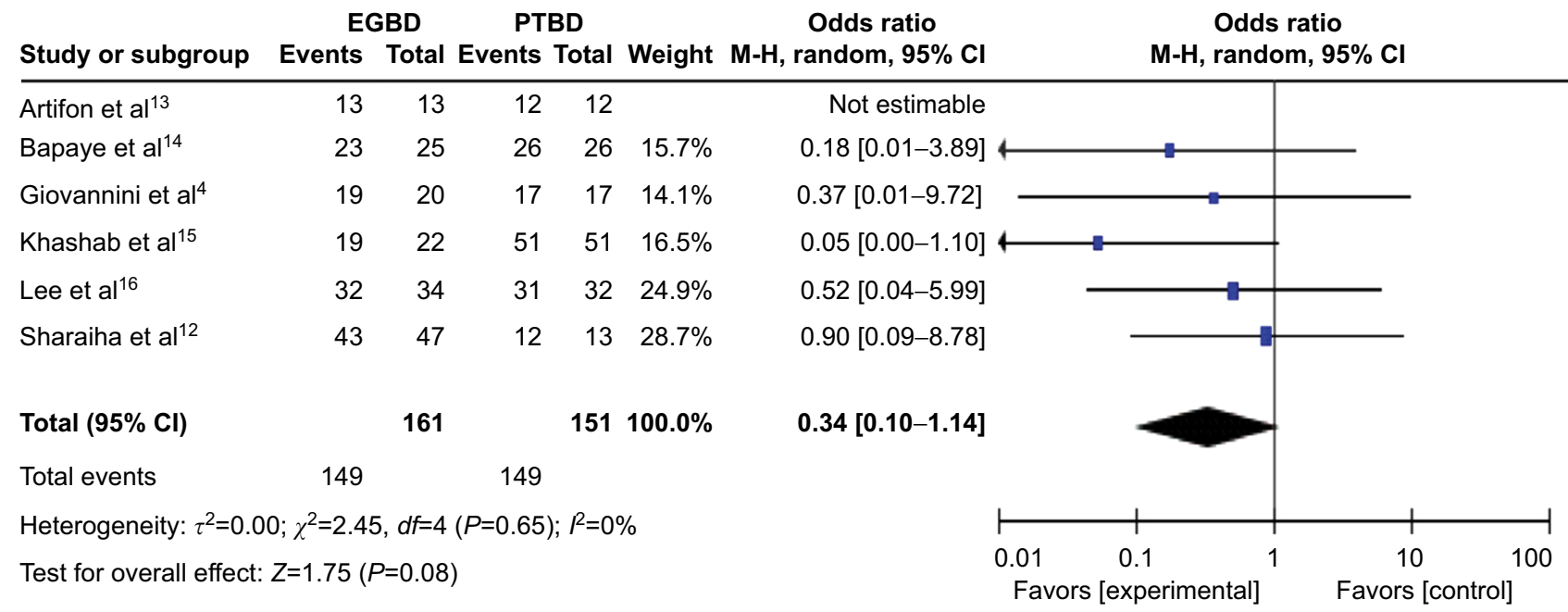

B

EGBD PTBD Odds ratio

Study or subgroup Events Total Events Total Weight $\mathrm{M}-\mathrm{H}$, random, $95 \% \mathrm{Cl}$

Artifon et al ${ }^{13}$
Bapaye et $\mathrm{al}^{14}$
Khashab et $^{14}{ }^{15}$
Lee et $\mathrm{al}^{16}$
Sharaiha et $\mathrm{al}^{12}$

Total $(95 \% \mathrm{Cl})$

Total events

128

151

$149100.0 \%$

132

Heterogeneity: $\tau^{2}=0.55 ; \chi^{2}=5.84, d f=4(P=0.21) ; P^{2}=32 \%$

Test for overall effect: $Z=0.65(P=0.51)$

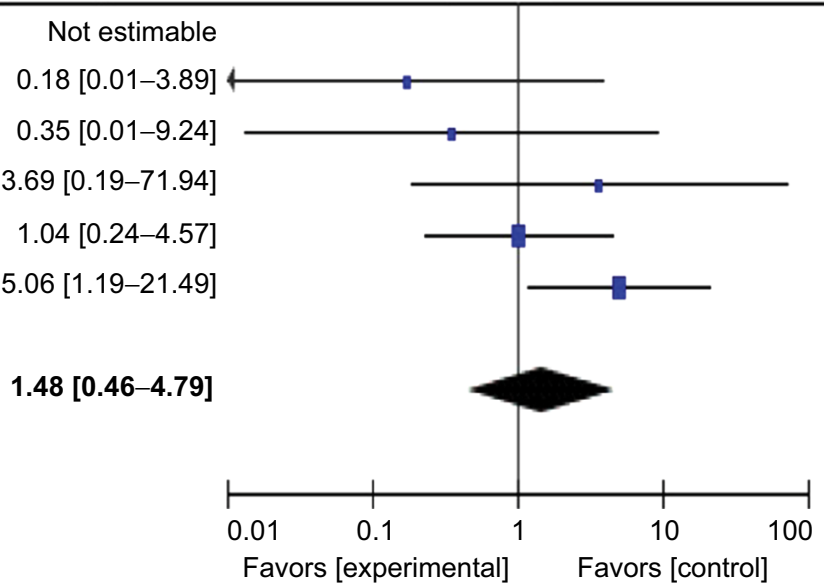

Odds ratio

M-H, random, $95 \% \mathrm{CI}$

Figure 2 (A) Forest plot of technical success and (B) forest plot of clinical success.

Abbreviations: EGBD, endoscopic ultrasound-guided biliary drainage; PTBD, percutaneous transhepatic biliary drainage; $M-H$, Mantel-Haenszel test.

The result of our study shows a similar success rate of both the procedures at this time. A high technical and functional success rate has been obtained in most clinical studies, as observed in a systemic review by Wang et al, of $94.71 \%$ and $91.66 \%$, respectively. ${ }^{36}$ This is partly because EGBD is being performed in high-volume centers by an experienced endoscopist. As the technique evolves, the success rate and the rate of complications of EGBD are bound to improve. At most centers, PTBD is an alternative procedure for failed ERCP. The development of EGBD, a technique that started just a decade ago as the fourth technique for biliary decompression (surgical drainage, percutaneous transhepatic drainage, endoscopic transpapillary drainage, EGBD), is currently replacing PTBD in high-volume centers. ${ }^{37}$ Although, at present, local expertise determines the type of technique used for biliary drainage in failed ERCP, EGBD is a less invasive and more physiologic technique. It provides better nutrition absorption, avoids electrolyte loss, requires fewer re-interventions and prevents the stress of external drain. ${ }^{38}$ If appropriate consent is obtained from the patient before ERCP, it can be done at a single setting.

EGBD is not without glitches. There are unique problems associated with EGBD at this time. This procedure is technically complex and diverse, with inherent risk of advanced endoscopy requiring specialized training and a steep learning curve. ${ }^{39}$ Therefore, EGBD is only feasible at high-volume therapeutic centers where appropriate interventional radiology and surgical backup are present. ${ }^{40}$ Otherwise, complications, such as bile leak, pneumoperitoneum, bleeding and stent 
A

EGBD PTBD Odds ratio

Study or subgroup Events Total Events Total Weight $\mathrm{M}-\mathrm{H}$, random, $95 \% \mathrm{Cl}$

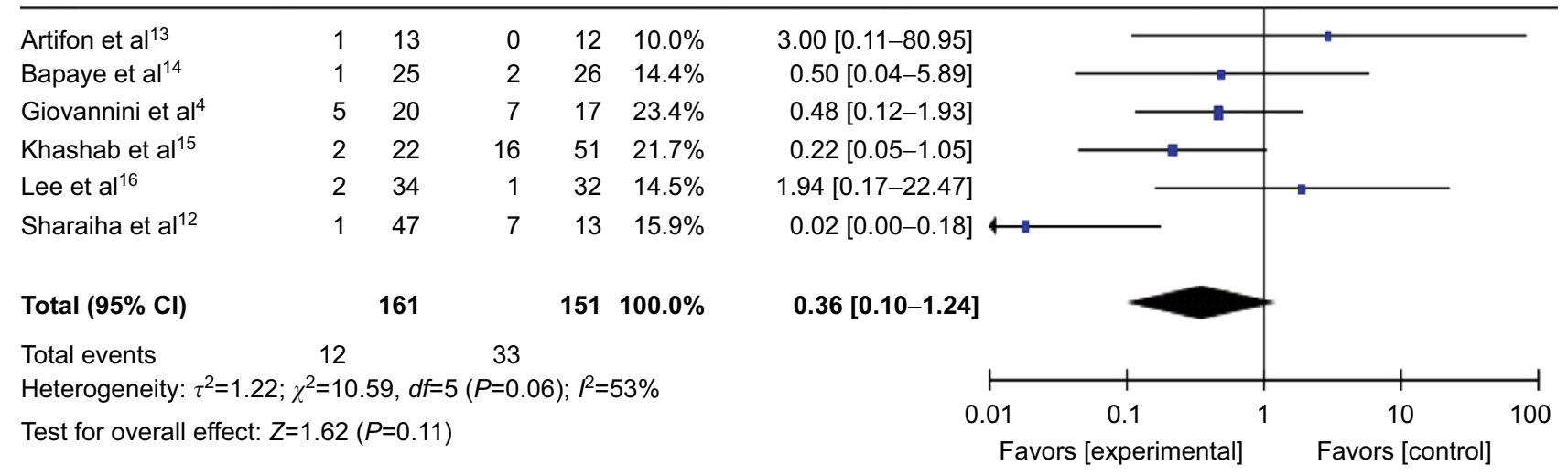

B

$\begin{array}{lll}\text { EGBD } & \text { PTBD } & \text { Odds ratio }\end{array}$

Study or subgroup Events Total Events Total Weight $\mathrm{M}-\mathrm{H}$, random, $95 \% \mathrm{Cl}$

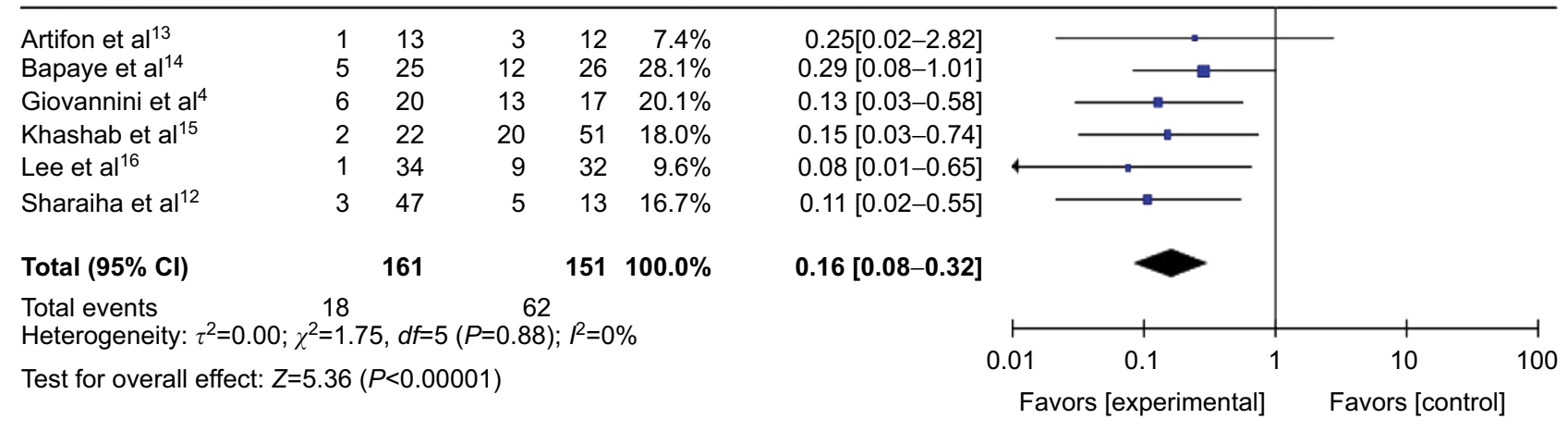

C

EGBD PTBD

Odds ratio

Odds ratio

Study or subgroup Events Total Events Total Weight $\mathrm{M}-\mathrm{H}$, random, $95 \% \mathrm{Cl}$ $\mathrm{M}-\mathrm{H}$, random, $95 \% \mathrm{Cl}$

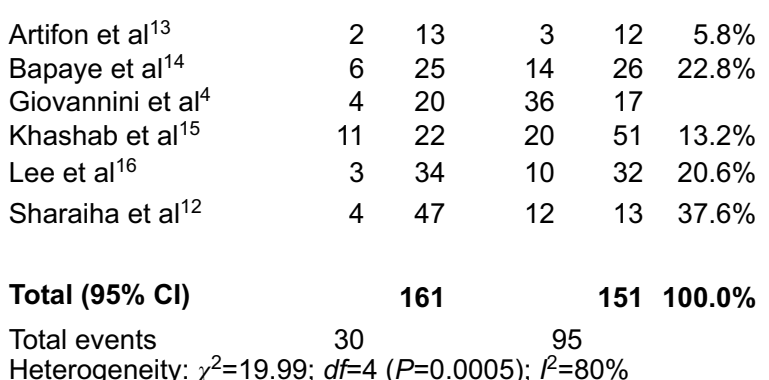

Heterogeneity: $\chi^{2}=19.99 ; d f=4(P=0.0005) ; l^{2}=80 \%$

Test for overall effect: $Z=3.85(P=0.0001)$

Figure 3 Forest plots of mild, moderate to severe, and total adverse events.

Notes: (A) Forest plot of mild adverse events; (B) forest plot of moderate to severe adverse events; (C) forest plot of total adverse events.

Abbreviations: EGBD, endoscopic ultrasound-guided biliary drainage; PTBD, percutaneous transhepatic biliary drainage; M-H, Mantel-Haenszel test.

migration, are likely to occur. ${ }^{41,42}$ There is a small theoretical risk of introducing infection in EGBD because of the invasion of sterile biliary tree by transmural puncture from the luminal side of the gastrointestinal tract. ${ }^{43}$ But, the overall adverse events are bound to improve as in-roads are being made for this noble technique. Although labeled as rescue therapy for failed ERCP, primary EGBD is being currently compared to ERCP, and a recent study found comparable short-term outcomes of EGBD and ERCP. ${ }^{44}$ Also, unlike ERCP, there is no risk of postprocedural pancreatitis. In the hands of expert endoscopists, clinical success rate and complications have not been found to be different in the two groups. ${ }^{44,45}$

\section{Conclusion}

EGBD is an effective alternative procedure when ERCP fails in terms of success rate and adverse events profile. As 
the technique is evolving, EGBD is replacing PTBD as the standard procedure of choice in cases of failed ERCP.

\section{Disclosure}

The authors report that no conflicts of interest in this work.

\section{References}

1. Varadarajulu S, Kilgore ML, Wilcox CM, Eloubeidi MA. Relationship among hospital ERCP volume, length of stay, and technical outcomes. Gastrointest Endosc. 2006;64(3):338-347.

2. Coté GA, Singh S, Bucksot LG, et al. Association between volume of endoscopic retrograde cholangiopancreatography at an academic medical center and use of pancreatobiliary therapy. Clin Gastroenterol Hepatol. 2012;10(8):920-924.

3. Enochsson L, Swahn F, Arnelo U, Nilsson M, Löhr M, Persson G. Nationwide, population-based data from 11,074 ERCP procedures from the Swedish Registry for Gallstone Surgery and ERCP. Gastrointest Endosc. 2010;72(6):1175-1184, 1184.e1-e3.

4. Giovannini M, Bories E, Napoleon B, Barthet M, Caillol F, Pesenti C. 855 multicenter randomized phase II study: percutaneous biliary drainage vs EUS guided biliary drainage : results of the intermediate analysis. Gastrointest Endosc. 2015;81(5):AB174.

5. Luu C, Lee B, Stabile BE. Choledochoduodenostomy as the biliaryenteric bypass of choice for benign and malignant distal common bile duct strictures. Am Surg. 2013;79(10):1054-1057.

6. Khajanchee YS, Cassera MA, Hammill CW, Swanström LL, Hansen PD. Outcomes following laparoscopic choledochoduodenostomy in the management of benign biliary obstruction. J Gastrointest Surg. 2012;16(4):801-805.

7. Spanheimer PM, Cyr AR, Liao J, et al. Complications and survival associated with operative procedures in patients with unresectable pancreatic head adenocarcinoma. J Surg Oncol. 2014;109(7):697-701.

8. Artifon EL, Sakai P, Cunha JE, et al. Surgery or endoscopy for palliation of biliary obstruction due to metastatic pancreatic cancer. $\mathrm{Am} \mathrm{J}$ Gastroenterol. 2006;101(9):2031-2037.

9. Laméris JS, Stoker J, Nijs HG, et al. Malignant biliary obstruction: percutaneous use of self-expandable stents. Radiology. 1991;179(3):703-707.

10. Piñol V, Castells A, Bordas JM, et al. Percutaneous self-expanding metal stents versus endoscopic polyethylene endoprostheses for treating malignant biliary obstruction: randomized clinical trial. Radiology. 2002;225(1):27-34.

11. Giovannini M, Moutardier V, Pesenti C, Bories E, Lelong B, Delpero JR. Endoscopic ultrasound-guided bilioduodenal anastomosis: a new technique for biliary drainage. Endoscopy. 2001;33(10):898-900.

12. Sharaiha RZ, Kumta NA, Desai AP, et al. Endoscopic ultrasound-guided biliary drainage versus percutaneous transhepatic biliary drainage: predictors of successful outcome in patients who fail endoscopic retrograde cholangiopancreatography. Surg Endosc. 2016;30(12):5500-5505.

13. Artifon EL, Aparicio D, Paione JB, et al. Biliary drainage in patients with unresectable, malignant obstruction where ERCP fails: endoscopic ultrasonography-guided choledochoduodenostomy versus percutaneous drainage. J Clin Gastroenterol. 2012;46(9):768-774.

14. Bapaye A, Dubale N, Aher A. Comparison of endosonography-guided vs. percutaneous biliary stenting when papilla is inaccessible for ERCP. United European Gastroenterol J. 2013;1(4):285-293.

15. Khashab MA, Valeshabad AK, et al. A comparative evaluation of EUS-guided biliary drainage and percutaneous drainage in patients with distal malignant biliary obstruction and failed ERCP. Dig Dis Sci. 2015;60(2):557-565.

16. Lee TH, Choi JH, Park do H, et al. Similar efficacies of endoscopic ultrasound-guided transmural and percutaneous drainage for malignant distal biliary obstruction. Clin Gastroenterol Hepatol. 2016;14(7):10111019.e3.

17. Beller EM, Glasziou PP, Altman DG, et al; PRISMA for Abstracts Group. PRISMA for Abstracts: reporting systematic reviews in journal and conference abstracts. PLoS Med. 2013;10(4):e1001419.
18. Tyberg A, Saumoy M, Sequeiros EV, et al. EUS-guided versus percutaneous gallbladder drainage: Isn't it time to convert? J Clin Gastroenterol. Epub 2016 Dec 22.

19. Choi JH, Kim HW, Lee JC, et al. Percutaneous transhepatic versus EUS-guided gallbladder drainage for malignant cystic duct obstruction. Gastrointest Endosc. 2017;85(2):357-364.

20. Torres-Ruiz MF, De La Mora-Levy JG, Alonso-Larraga JO, Del Monte JS, Hernandez-Guerrero A. Su1337 biliary drainage in malignant obstruction: a comparative study between EUS-guided vs percutaneous drainage in patients with failed ERCP. Gastrointest Endosc. 2016;83(5):AB356.

21. Püspök A, Lomoschitz F, Dejaco C, Hejna M, Sautner T, Gangl A. Endoscopic ultrasound guided therapy of benign and malignant biliary obstruction: a case series. Am J Gastroenterol. 2005;100(8):1743-1747.

22. Itoi T, Itokawa F, Sofuni A, et al. Endoscopic ultrasound-guided choledochoduodenostomy in patients with failed endoscopic retrograde cholangiopancreatography. World J Gastroenterol. 2008;14(39):6078-6082.

23. Smith AC, Dowsett JF, Russell RC, Hatfield AR, Cotton PB. Randomised trial of endoscopic stenting versus surgical bypass in malignant low bileduct obstruction. Lancet. 1994;344(8938):1655-1660.

24. Ferrucci JT Jr, Mueller PR, Harbin WP. Percutaneous transhepatic biliary drainage: technique, results, and applications. Radiology. 1980;135(1):1-13.

25. Harbin WP, Mueller PR, Ferrucci JT Jr. Transhepatic cholangiography: complicatons and use patterns of the fine-needle technique: a multiinstitutional survey. Radiology. 1980;135(1):15-22.

26. Bahra M, Jacob D. Surgical palliation of advanced pancreatic cancer. Recent Results Cancer Res. 2008;177:111-120.

27. Gupta K, Mallery S, Hunter D, Freeman ML. Endoscopic ultrasound and percutaneous access for endoscopic biliary and pancreatic drainage after initially failed ERCP. Rev Gastroenterol Disord. 2007;7(1):22-37.

28. Nennstiel S, Weber A, Frick G, et al. Drainage-related complications in percutaneous transhepatic biliary drainage. J Clin Gastroenterol. 2015;49(9):764-770.

29. Song TJ, Park DH, Eum JB, et al. EUS-guided cholecystoenterostomy with single-step placement of a $7 \mathrm{~F}$ double-pigtail plastic stent in patients who are unsuitable for cholecystectomy: a pilot study (with video). Gastrointest Endosc. 2010;71(3):634-640.

30. Súbtil JC, Betes M, Muñoz-Navas M. Gallbladder drainage guided by endoscopic ultrasound. World J Gastrointest Endosc. 2010;2(6):203-209.

31. Choi JH, Lee SS, Choi JH, et al. Long-term outcomes after endoscopic ultrasonography-guided gallbladder drainage for acute cholecystitis. Endoscopy. 2014;46(8):656-661.

32. Widmer J, Alvarez P, Gaidhane M, et al. Endoscopic ultrasonographyguided cholecystogastrostomy in patients with unresectable pancreatic cancer using anti-migratory metal stents: a new approach. Dig Endosc. 2014;26(4):599-602.

33. Jang JW, Lee SS, Park DH, Seo DW, Lee SK, Kim MH. Feasibility and safety of EUS-guided transgastric/transduodenal gallbladder drainage with single-step placement of a modified covered self-expandable metal stent in patients unsuitable for cholecystectomy. Gastrointest Endosc. 2011;74(1):176-181.

34. Irani S, Baron TH, Grimm IS, Khashab MA. EUS-guided gallbladder drainage with a lumen-apposing metal stent (with video). Gastrointest Endosc. 2015;82(6):1110-1115.

35. Teoh AY, Binmoeller KF, Lau JY. Single-step EUS-guided puncture and delivery of a lumen-apposing stent for gallbladder drainage using a novel cautery-tipped stent delivery system. Gastrointest Endosc. 2014;80(6): 1171.

36. Wang K, Zhu J, Xing L, Wang Y, Jin Z, Li Z. Assessment of efficacy and safety of EUS-guided biliary drainage: a systematic review. Gastrointest Endosc. 2016;83(6):1218-1227.

37. Itoi T. Moving closer to developing an optimal algorithm for EUS-guided biliary drainage. Gastrointest Endosc. 2016;84(6):947-949.

38. Holt BA, Hawes R, Hasan M, et al. Biliary drainage: role of EUS guidance. Gastrointest Endosc. 2016;83(1):160-165.

39. James PD, Antonova L, Martel M, Barkun A. Measures of trainee performance in advanced endoscopy: a systematic review. Best Pract Res Clin Gastroenterol. 2016;30(3):421-452. 
40. Kahaleh M, Artifon EL, Perez-Miranda M, et al. Endoscopic ultrasonography guided biliary drainage: summary of consortium meeting, May 7th, 2011, Chicago. World J Gastroenterol. 2013;19(9):1372-1379.

41. Nakai Y, Isayama H, Yamamoto N, et al. Safety and effectiveness of a long, partially covered metal stent for endoscopic ultrasound-guided hepaticogastrostomy in patients with malignant biliary obstruction. Endoscopy. 2016;48(12):1125-1128.

42. Kawakubo K, Isayama $H$, Kato $H$, et al. Multicenter retrospective study of endoscopic ultrasound-guided biliary drainage for malignant biliary obstruction in Japan. J Hepatobiliary Pancreat Sci. 2014;21(5):328-334.
43. Lakhtakia S. Complications of diagnostic and therapeutic Endoscopic Ultrasound. Best Pract Res Clin Gastroenterol. 2016;30(5): 807-823.

44. Dhir V, Itoi T, Khashab MA, et al. Multicenter comparative evaluation of endoscopic placement of expandable metal stents for malignant distal common bile duct obstruction by ERCP or EUS-guided approach. Gastrointest Endosc. 2015;81(4):913-923.

45. Kawakubo K, Kawakami H, Kuwatani M, et al. Endoscopic ultrasoundguided choledochoduodenostomy vs. transpapillary stenting for distal biliary obstruction. Endoscopy. 2015;48(2):164-169.
Clinical and Experimental Gastroenterology

\section{Publish your work in this journal}

Clinical and Experimental Gastroenterology is an international, peerreviewed, open access, online journal publishing original research, reports, editorials, reviews and commentaries on all aspects of gastroenterology in the clinic and laboratory. This journal is included on PubMed. The manuscript management system is completely online
Dovepress

and includes a very quick and fair peer-review system, which is all easy to use. Visit http://www.dovepress.com/testimonials.php to read real quotes from published authors. 